\title{
Seasonal Variation in the Growth, Body Composition, and Diet of Clethrionomys gapperi in Spruce Forest
}

\author{
M. R. PERRIN ${ }^{1}$
}

Perrin M. R., 1979: Seasonal variation in the growth, body composition, and diet of Clethrionomys gapperi in spruce forest. Acta theriol., 24, 23: 299-318 [With 3 Tables \& 8 Figs.].

Growth and body composition of Clethrionomys gapperi (Vigors, 1830) were examined in relation to season and diet for a population inhabiting black spruce (Picea mariana) forest in southeastern Manitoba. Winter weight loss, thought to be an adaptive mechanism for conserving energy during long cold winters, is associated with dehydration, and not attributable to population age structure, or, to any obvious change in diet. Spring growth and increased protein content occurred earlier in males than females and was not a response to a changing diet, but was temporally associated with sexual maturation and daylength changes. Protein and ash levels were usually stable, even during pregnancy, but altered when vole numbers declined during the winter of 1974 . Seasonal changes in diet were apparent, and more proteinaceous food was taken in summer than winter, probably reflecting availability. This may have affected maternal nutrition and the growth and survival of young animals but the onset and termination of reproduction was not related to changes in the diet. A decline in numbers was associated with poor snow cover, fat depletion and protein loss, although diet was unchanged in relation to the previous year. Mortality may have resulted from a decline in food quality when energy demands for thermoregulation and maintenance were high, or lack of snow cover may have affected the vole's feeding behaviour and caused greater exposure to predators.

[Environmental Res. Branch Whiteshell Nuclear Res. Establishment, Atomic Energy of Canada Ltd., Pinawa, Manitoba, Canada, ROE 1LO].

\section{INTRODUCTION}

Growth of individual animals in cyclic populations is important because it is tied to the primary processes of birth, death and dispersal (K r e b s \& M y e r s 1974). In this paper, growth and body composition of the redbacked vole (Clethrionomys gapperi) are related to seasonal and dietary changes. The absence of winter growth in C. gapperi, as in

1 Present address: Dept. Zool. Entomol., Rhodes Univ., P.O. Box 94, Grahamstown, 6140, South Africa. 
other microtines (Bergstedt, 1965; Hyvärinen \& Heikura, 1971; Iverson \& Turner, 1974), is examined in terms of energy conservation and adaptation to a cold environment, and related to the differential growth rates between cohorts $(\mathrm{Z} \mathrm{e} \mathrm{j} \mathrm{d} \mathrm{a,} \mathrm{1971).} \mathrm{The} \mathrm{roles} \mathrm{of}$ fat and dehydration in the metabolism of C. gapperi are compared to those observed in other rodents ( $\mathrm{F} \mathrm{e} \mathrm{d} \mathrm{y} \mathrm{k,} \mathrm{1974;} \mathrm{H}$ a y w a r d, 1965; S a wicka-K a pusta, 1968; Whitney, 1973).

Diet is examined because of its influence on growth and body composition, and hence reproduction (F i e ld, 1975) and rates of population increase. Seasonal changes in the feeding habits of $C$. gapperi are related to Hansson's (1972) hypothesis which suggests that summer diets are proteinaceous whereas winter diet quality is poor and largely carbohydrate. Finally, the cause of a drastic decline in C. gapperi numbers was examined with reference to body composition.

\section{METHODS}

The population of C. gapperi studied was situated $2.8 \mathrm{~km}$ northeast of the Whiteshell Nuclear Research Establishment at Pinawa, southeastern Manitoba, in black spruce (Hicea mariana) forest. Sphagnum covered about half of the forest floor, and the commonest shrubs were Ledum groenlandicum and Rubus idaeus, with Rubus pubescens, Vaccinium oxycoccos and Cornus canadensis as the commonest herbs (Perrin, in press; I verson \& Turner, 1973).

Lines of approximately 100 Museum Special snap-traps baited with peanut-butter were set at $10 \mathrm{~m}$ intervals biweekly for four consecutive nights from November 1973 to December 1974. Reproductive tracts were collected by autopsy, and the lower jaws were removed from each of 600 weighed and measured specimens to determine age (Perrin, 1978).

The alimentary tracts were removed and a random sample of ten stomachs per month was examined to determine feeding habits. After washing, the stomach contents were treated with concentrated nitric acid, which causes partial destruction of mesophyll and allows cuticle to separate (Pulkinen, 1971). Further separation of these components with $1 \%$ iron alum solution was followed by clearing with concentrated chloral hydrate solution (Pulkinen, 1971). Fragments were then suspended in $1 \%$ periodic acid, washed, and stained with Schiff's reagent and fast green. Two slides were prepared from each sample and counts of identified items on five parallel transects of each slide were used to determine the relative abundance of the various dietary items. Identified items were placed into one of seven categories, i.e. monocotyledonous leaves, dicotyledonous leaves, vascular tissue, moss, lichen, seeds, and insects. No attempt was made to identify items in the diet to species because of: (1) the great inherent variability in plant epidermal structure (E s a u, 1967; Linsbauer, 1930; A very, 1933; W a t s o n, 1942; Metcalfe \& Chalk, 1972); (2) the differential digestibility of dicotyledons and sedges compared to grasses ( $N$ e a l, Pulkinen \& O we n 1973); and (c) the presence of cuticular digestion by rodents (Shenk, Elliot \& Thomas, 1970; Pulkinen, 1971).

Body composition analyses were used to determine water, fat, protein and ash 
(mineral) content. After dehydration at $80^{\circ} \mathrm{C}$ the dried carcasses were fat-extracted by the Soxhlet technique to determine lean dry weight (Allen, Grims ha w \& Parkinson, 1974). Carcasses were then finely ground in a Wiley Mill prior to nitrogen and ash content determination. The Kjeldahl method using $0.5 \mathrm{~g}$ samples, titanium dioxide as a catalyst (Willi a ms, 1973) and a 6.25 conversion factor was applied (A $11 \mathrm{e} \mathrm{n}$ et al., 1974). For mineral (ash) determination, a $1.0 \mathrm{~g}$ dried sample was heated to $600^{\circ} \mathrm{C}$ for two hours in a Muffle furnace and reweighed after cooling. The residue left after cooling is a measure of total mineral content (A 11 en et al., 1974). Seasonal variations in body composition were examined by Students $t$ tests while correlation analyses were performed between lean dry weight and the various body components for each season.

A nearby grid was live-trapped biweekly alternating with snap-trapping to provide information on population demography (Perrin, in press). Seasons were separated as follows: autumn 1973 (November and December), winter (January to March), spring (April to July, overwintered adults only), summer (June to September, young of the year only), and autumn 1974 (October to December). All specimens were placed into one of fourteen monthly age classes ( $\mathrm{Per}$ in, 1978). Juveniles were sexually immature voles weighing $\leqslant 18 \mathrm{~g}$; sub-adults were heavier, but were of indefinite reproductive status, i.e., females might have possessed a perforate vagina but were not pregnant or lactating, males had scrotal testes but undeveloped ancillary glands; adults were mature pregnant or lactating females and potent males.

\section{RESULTS}

Lean dry weight varied seasonally (Fig. 1), but growth was inhibited in winter. Males were significantly heavier than females in spring when growth in males preceded that of females. In July, sub-adult females were significantly heavier than sub-adult males. This difference was not caused by pregnancy but was associated with sexual maturation in females of the year. Greatest body weights were reached in June by overwintered adults and in October by young of the year. Maximum adult weights were only attained after overwintering had occurred. Seasonal changes in body weight were significant, except for female voles entering the first (1973-4) winter (Table 1). Also, voles were significantly heavier in the autumn of 1974 than in the autumn of 1973.

The same growth pattern was exhibited when changes in body length were considered (Fig. 2). Males were longer than females in spring when growth rates were high, but the converse was true in summer and autumn. Voles in the autumn of 1974 were longer but also older than those of the previous autumn.

Significant levels (Table 1) of carcass dehydration occurred in winter (Fig. 3). In June, there was a large significant difference in water content between overwintered adults and young of the year. There were no significant differences in carcass water content between the autumns of 1973 and 1974. 
Fat was a variable carcass component, and although peak levels occurred in summer, there was little to suggest a seasonal pattern (Fig. 4) unless it was bimodal. Significant sex and generation differences in fat content occurred only during mid-summer. High fat levels in January and August preceded periods of growth in spring and autumn in overwintered adults and young of the year respectively.

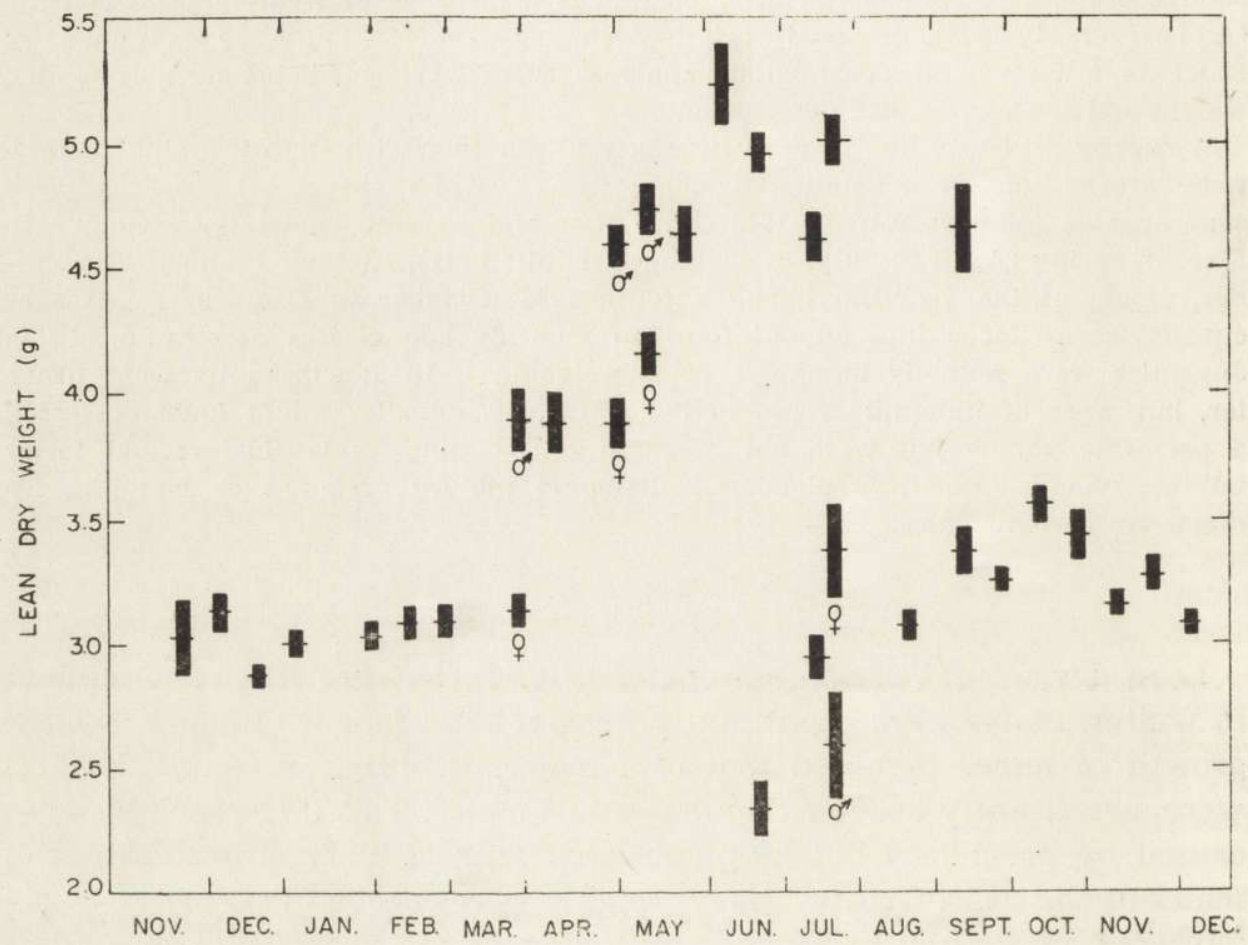

Fig. 1. Lean dry weight ( \pm standard error) of wild C. gapperi throughout the sample period. Males $\left(\sigma^{*}\right)$ are indicated separately from females ( $q$ ) where significant differences $(p<0.05)$ occur between the sexes $(\mathrm{N}=543)$.

Only small seasonal changes occurred in protein content (Fig. 5). Significant sex differences occurred only in June and September, and there was a solitary significant difference between overwintered and spring generations in July. Protein content of males increased significantly between winter and spring, while that of females increased later, between spring and summer (Table 1). Protein levels were lower at the end of 1974 than for the same period in 1973, but not significantly so.

Ash content was approximately constant but some seasonal fluctuation was evident (Fig. 6). Males exhibited small but significant seasonal differences, with increases in winter and summer (Table 1). Females lost 


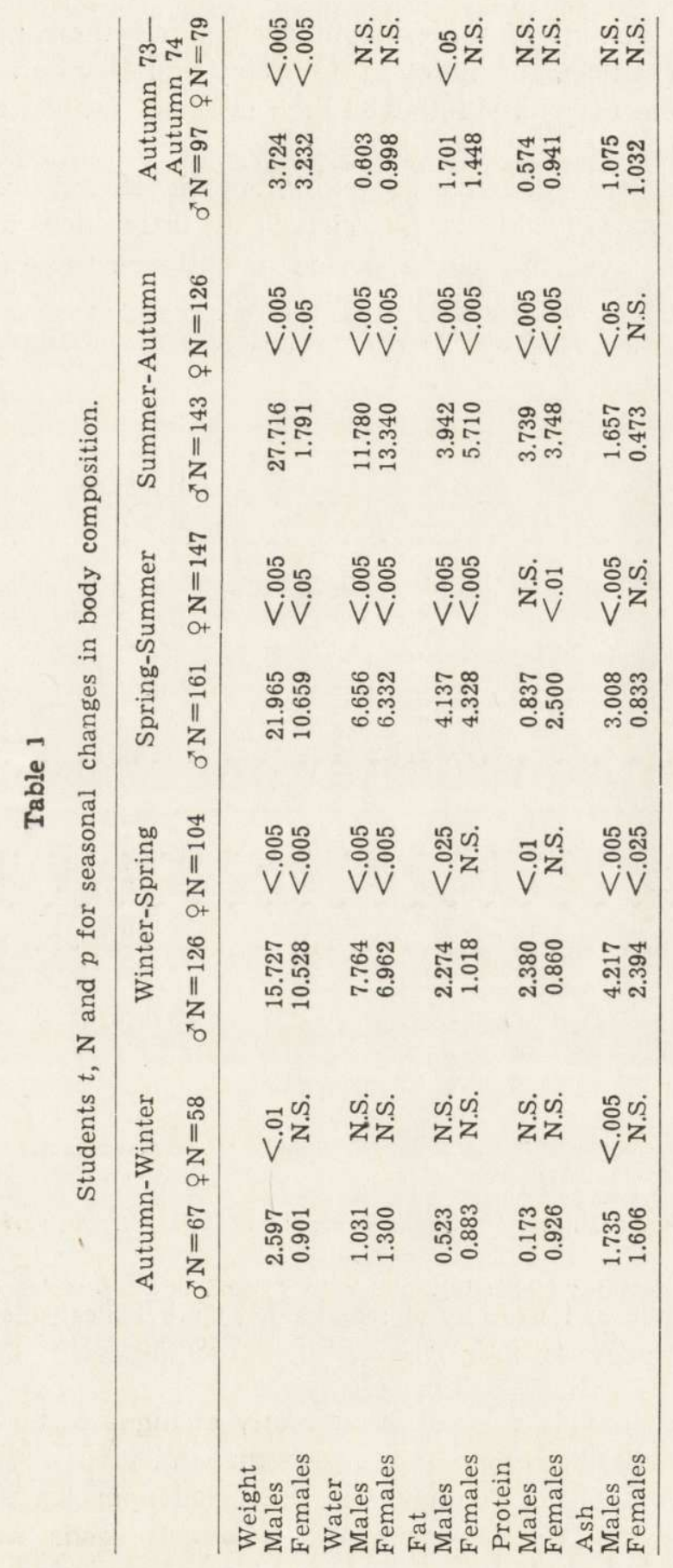


a significant amount of minerals in spring, but their mineral contemt was greater than that of males in February and October. High levels of mineral content may have followed high levels of fat content, and occurred twice annually.

While most body constituents exhibited significant differences over the summer period (Table 1), few significant differences in body composition occurred over the winter period or between the autumns of 1973 and 1974. Much of the variation in the body composition data, except for fat content, was explained by correlation with changes in lean dry

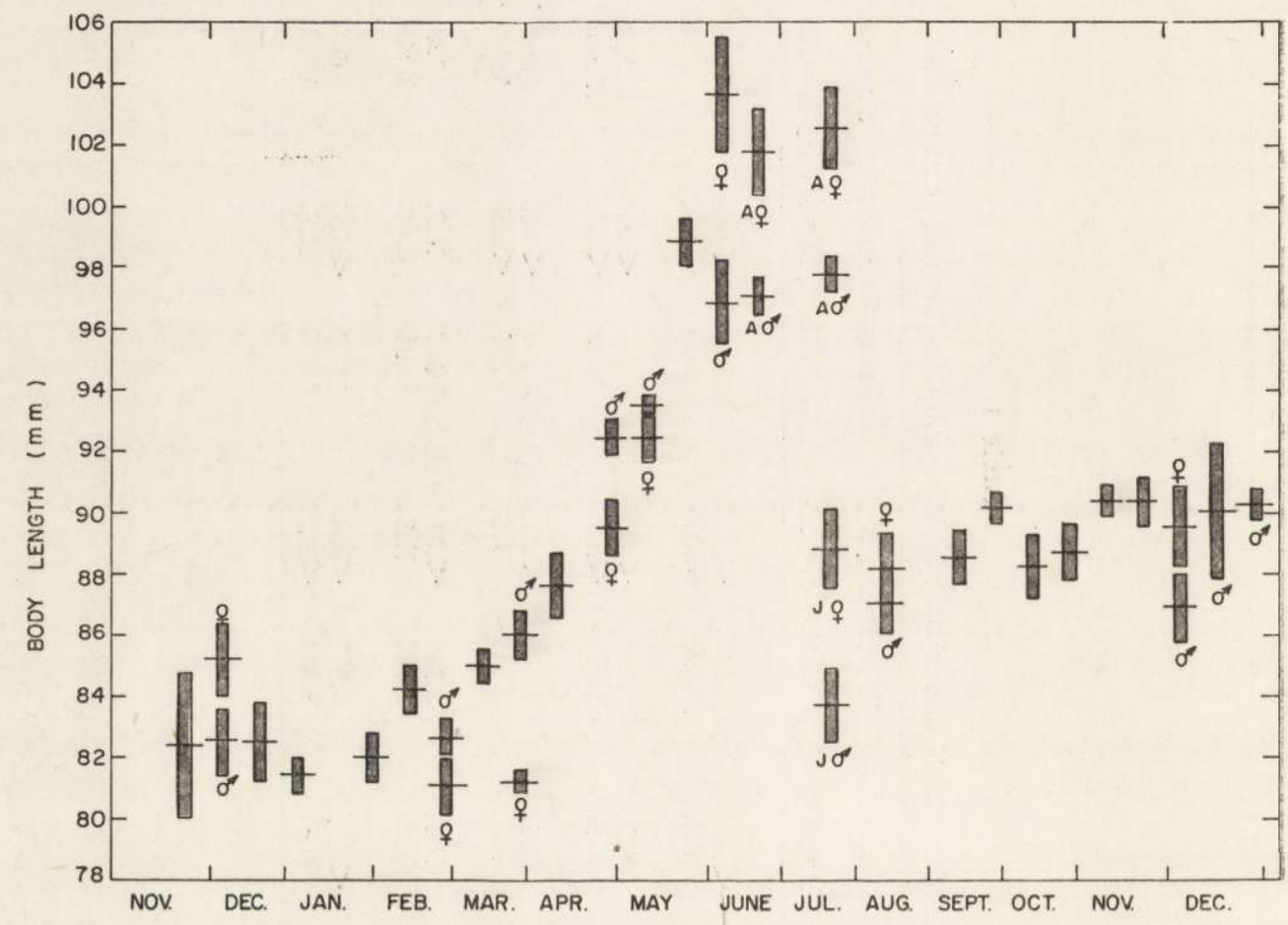

Fig. 2. Mean body length ( \pm standard error) of wild $C$. gapperi throughout the sample period.

Males $\left(\sigma^{x}\right)$ and females ( $\%$, adult males $\left(A \sigma^{x}\right)$ and adult females (A $q$ ), and, subadult and juvenile males $\left(\mathrm{J} \sigma^{\top}\right)$ and females $(\mathrm{J}+)$ are indicated separately where significant differences $(p<0.05)$ occur between these classes $(N=543)$.

weight (Table 2). This suggests that many changes in body composition are related to changes in weight or growth.

The major dietary component was dicotyledonous leaves, particularly in spring and late autumn (Fig. 7). However, seeds were important throughout the breeding season when few dicots were taken; insects were also taken at this time. The commonest large seeds were from 
Vaccinium, Rosa and Rubus species, but a much wider variety of smaller species was eaten. The commonest insects recorded were ants and the forest tent caterpillar (Malacosoma disstria), but many species were unidentifiable. Vascular plant tissue, lichens, mosses, and monocots form-

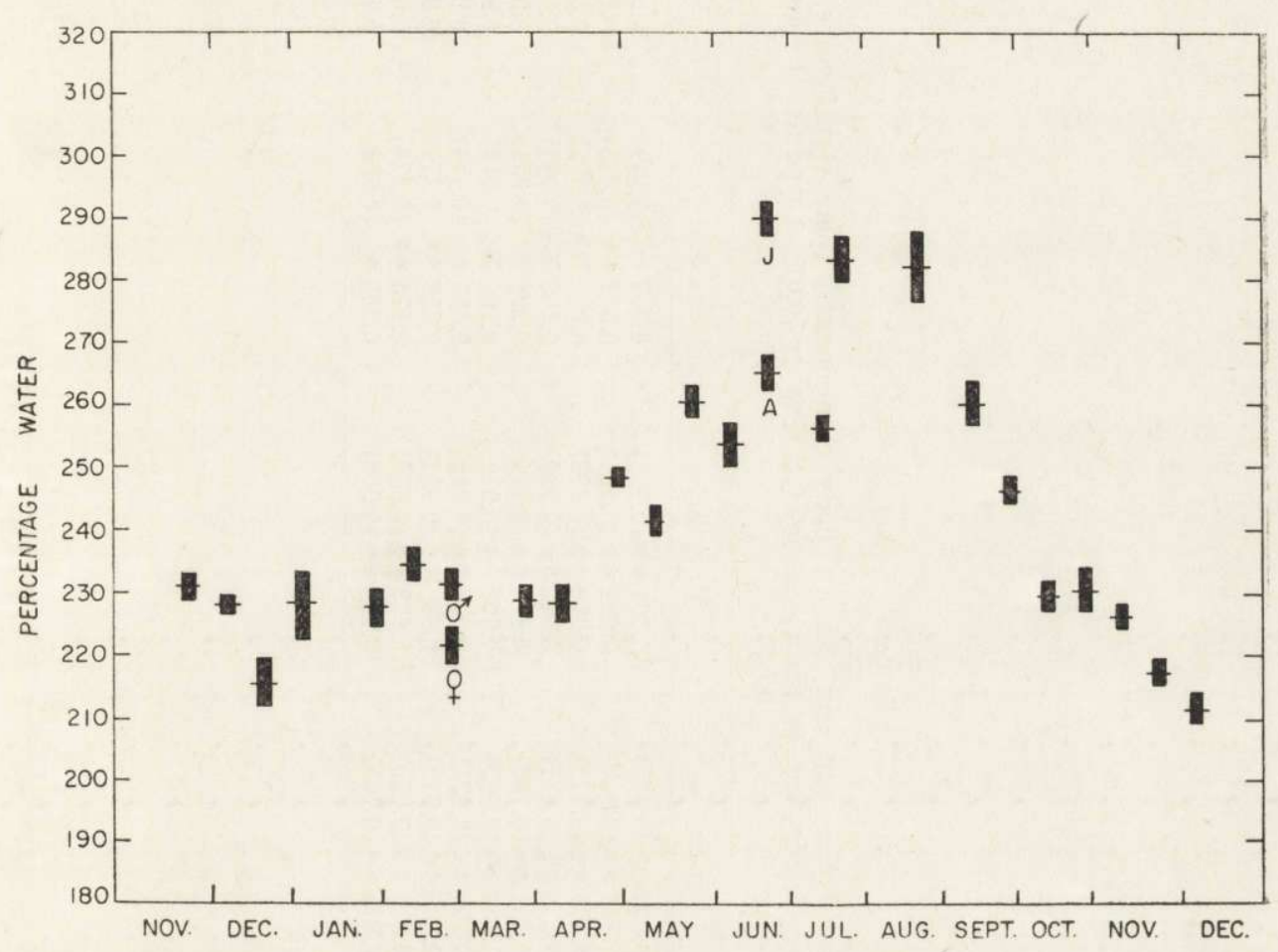

Fig. 3. Mean water content ( \pm standard error) of wild C. gapperi throughout the sample period.

Water content is expressed as a percentage of lean dry weight. Males $\left(\sigma^{7}\right)$, females $(q)$, adults (A), and sub-adults and juveniles (J) are indicated separately, where significant differences $(p<0.05)$ occur between these classes $(\mathrm{N}=543)$.

ed a small but stable component of the diet throughout the year.

Population numbers were stable throughout the first winter of the study, increased in spring to a peak in August (when maximum recruitment and loss occurred), and declined steadily thereafter (Fig. 8). The decline produced an extremely low density at the end of regular trapping in December 1974. In May 1975 numbers were still very low, as demonstrated by removal trapping for five days, after a week's prebaiting. None of the animals captured in December 1974 were retrapped in May 1975 (Table 3), but during the previous winter 59\% of the voles captured in December were present in May and had survived the inter- 


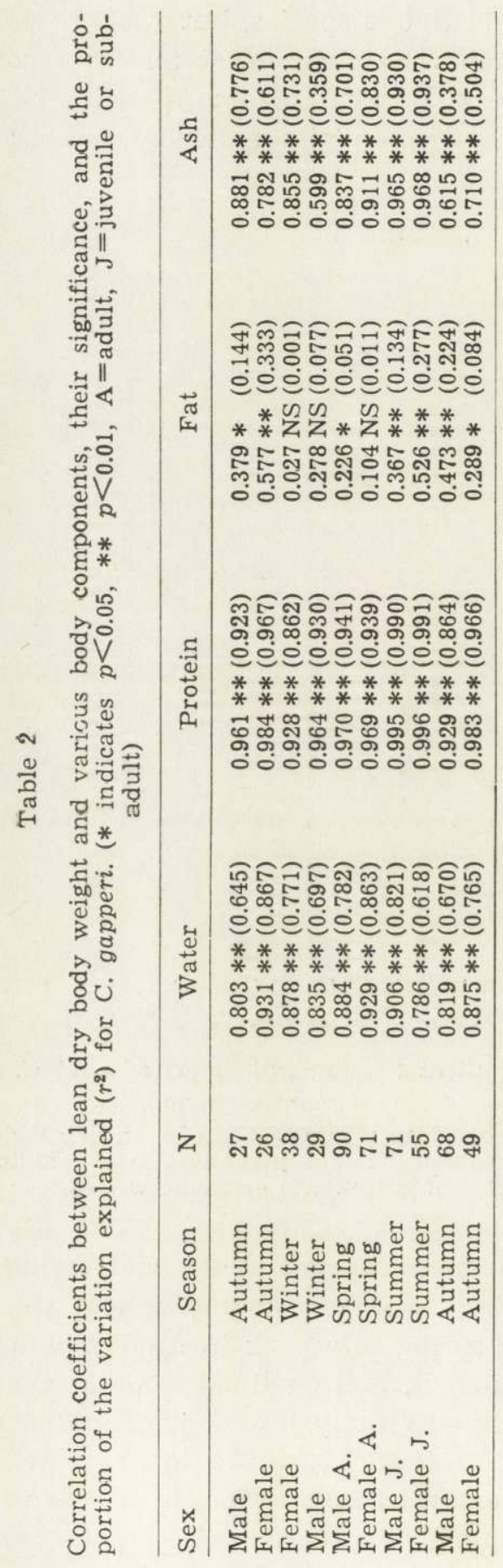


vening period. Thus, overwinter mortality was much greater in 1974/5 than in 1973/4.

Table 3

Numbers of overwintering C. gapperi.

\begin{tabular}{lcccc}
\hline Season & Mid-Nov. & Late Dec. & Mid-May & $\begin{array}{c}\text { Numbers recaptured } \\
\text { in May from } \\
\text { previous December }\end{array}$ \\
\hline $1973 / 4$ & 9 & 17 & 18 & 10 \\
$1974 / 5$ & 21 & 5 & 4 & 0 \\
\hline
\end{tabular}

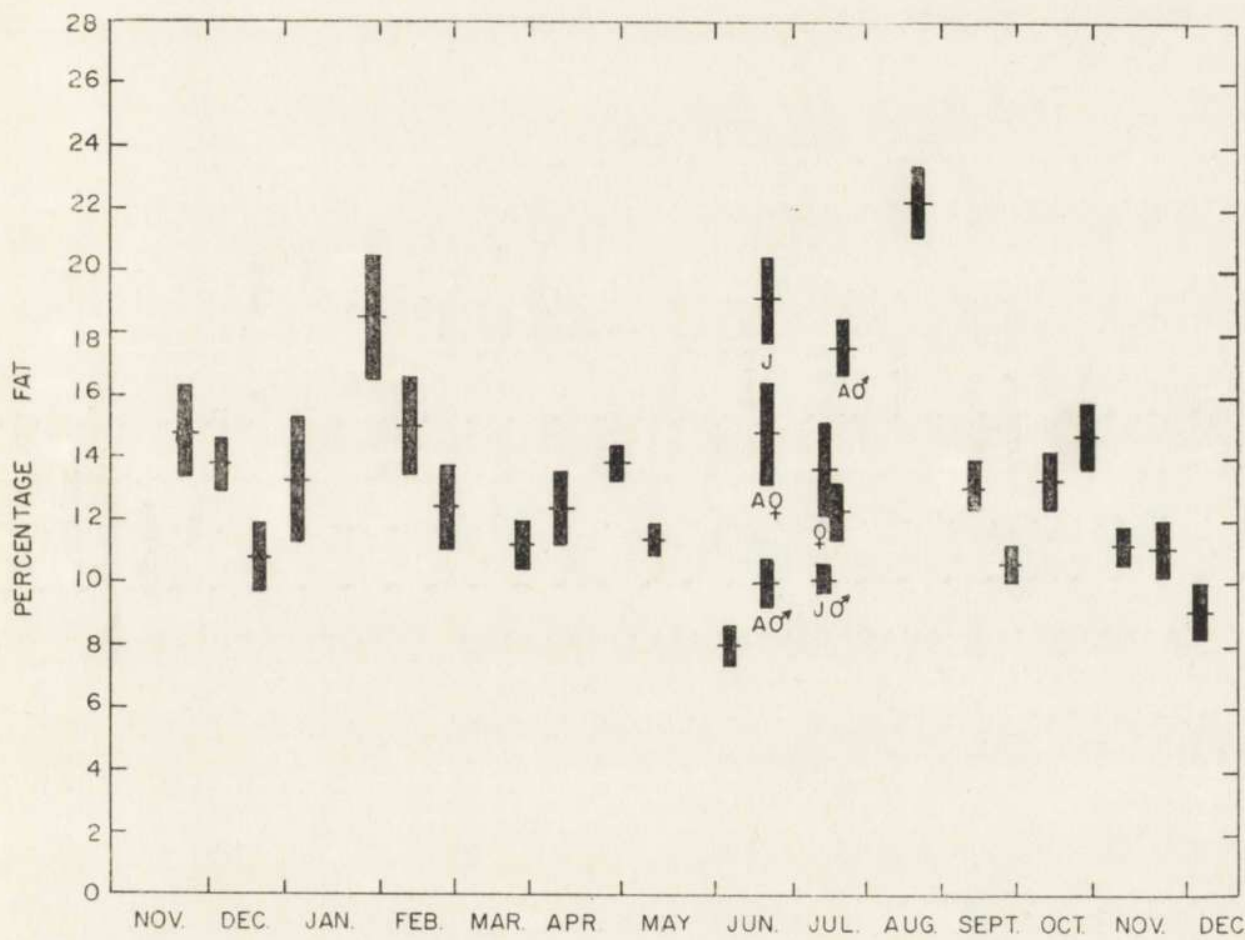

Fig. 4. Mean fat content ( \pm standard error) of wild C. gapperi throughout the sample period.

Fat content is expressed as a percentage of lean dry weight. Adult males $\left(A \sigma^{\top}\right)$, adult females (A $q$ ), females ( $(9)$, sub-adult and juvenile males $\left(\mathrm{J} \sigma^{\top}\right)$, and sub-adults and juveniles $(\mathrm{J})$, are indicated separately, where significant differences $(p<0.05)$ occur between these classes $(\mathrm{N}=543)$

\section{DISCUSSION}

Growth in C. gapperi was confined to the period following birth and to the season of sexual maturation but was retarded in winter, a pattern 
which is typical of other northern Clethrionomys populations (Boik ova \& Boikov, 1972; B u jalska \& Gliwicz, 1968 ; H y värinen and Heikura 1971; Fuller, Stebbins \& Dyke, 1969; Zej$\mathrm{d} a, 1971)$. The absence of winter growth is common to other microtines and murids (Iverson \& Turner, 1974; Brown, 1973; Hay w a rd, 1965; H a n s s o n, 1972) and appears to be a general phenomenon among cold-climate rodents.

Lower mean winter weights did not result from a younger population age structure since weight loss followed the cessation of breeding (P e r -

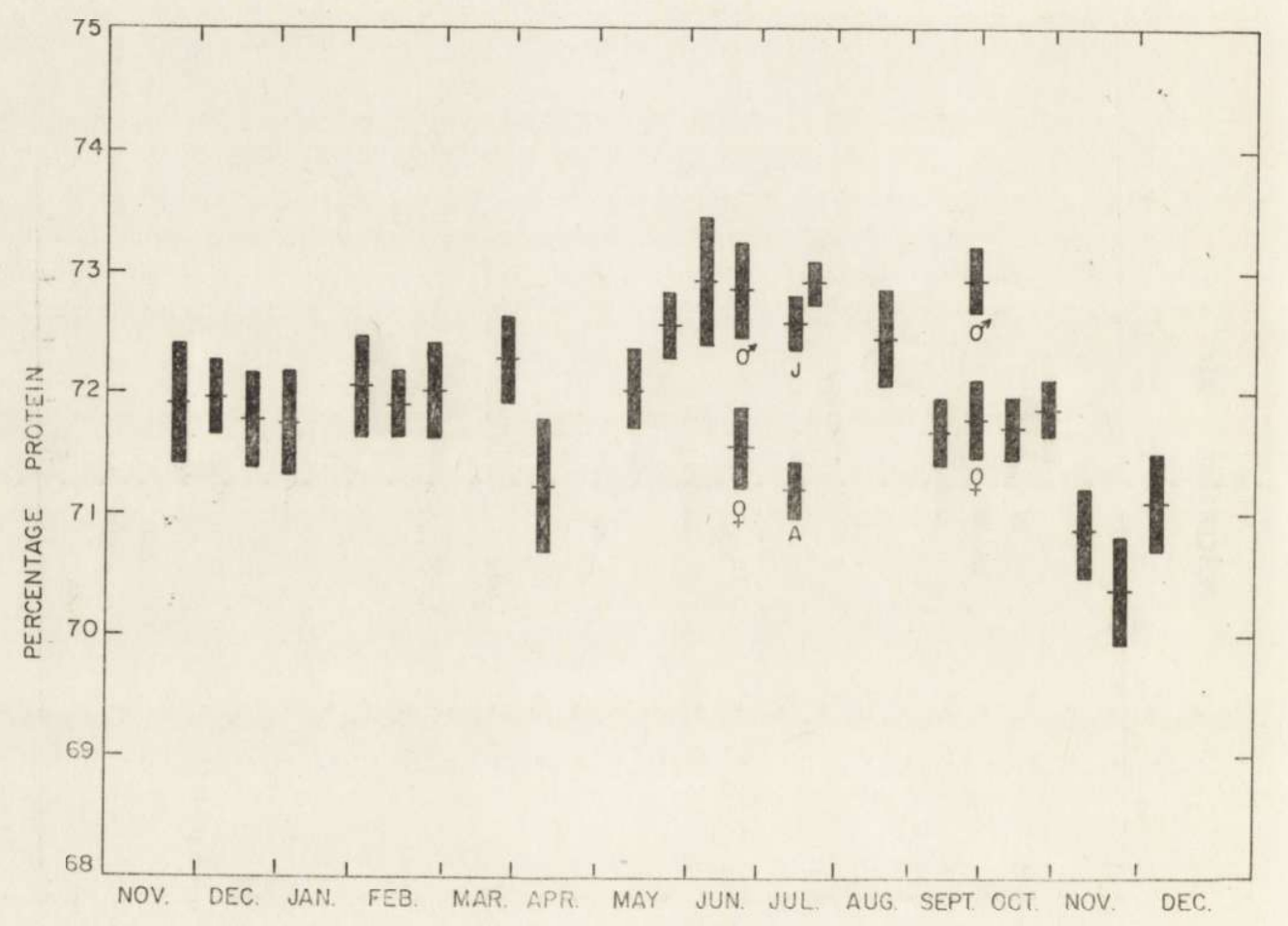

Fig. 5. Mean protein content ( \pm standard error) of wild C. gapperi throughout the sample period.

Protein content is expressed as a percentage of lean dry weight. Males $\left(\sigma^{\top}\right)$, females $(q)$, adults (A), and, sub-adults and juveniles (J), are indicated separately where significant differences $(p<0.05)$ occur between these classes $(N=543)$

ri in, in prep.). Direct weight loss $(7 \%)$ was demonstrated by 11 voles marked on 1 November and reweighed on 30 December. Similarly, winter weight loss is not attributable to population age structure in Clethrionomys rutilus (Boikova \& Boikov, 1972) and has been demon- 
strated within age classes of Clethrionomys glareolus ( $\mathrm{Z} \mathrm{e} \mathrm{j} \mathrm{da,} \mathrm{1971;}$ H y värinen \& H e ikura, 1971).

Loss of heavy individuals in autumn might also contribute to a decrease in mean body weight. Since only young of the year overwinter (P e r rin, in prep.) such changes, if present, must be based on differences in survival between individuals born in the same season, thus involving the complex problem of differential growth between cohorts

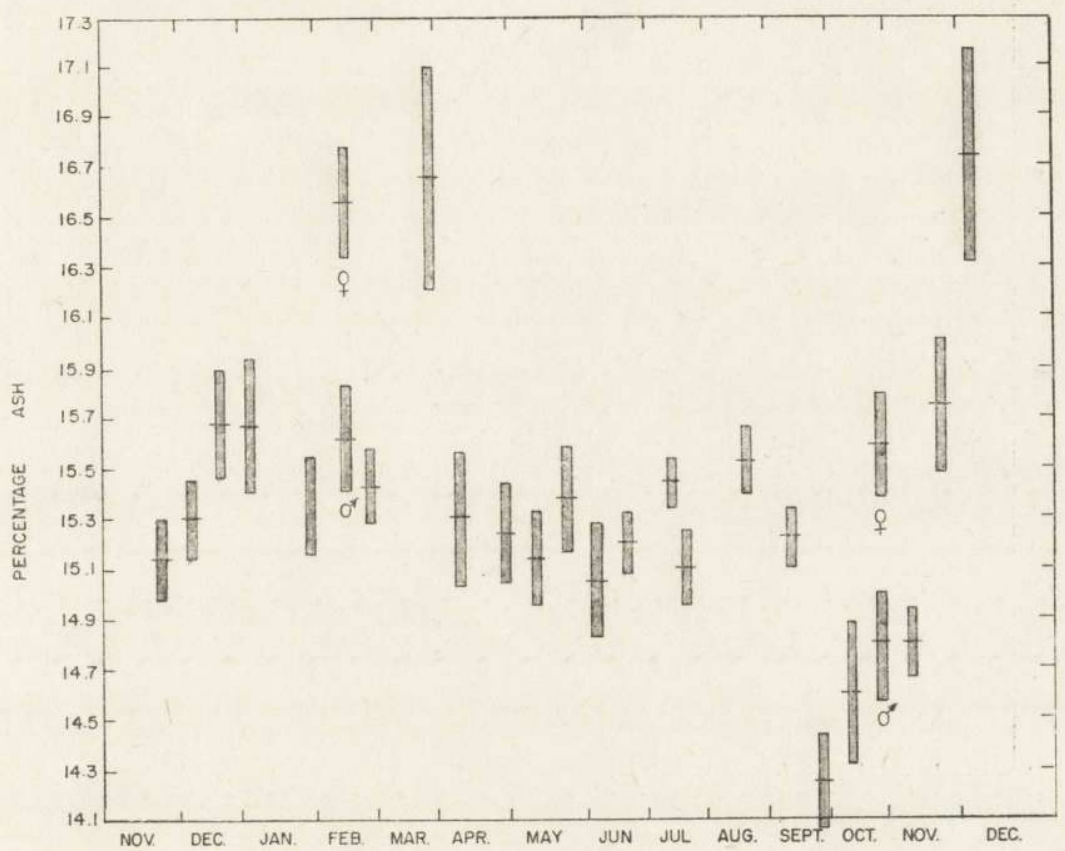

Fig. 6. Mean ash content ( \pm standard error) in wild C. gapperi throughout the sample period.

Ash content is expressed as a percentage of lean dry weight. Males $\left(\sigma^{x}\right)$ and females (q) are indicated separately where significant differences $(p<0.05)$ occur between the sexes $(\mathrm{N}=543)$.

(Z e j d a, 1971) as in C. glareolus. However, only first cohort (i.e., born before June 1) C. gapperi matured and gained weight in the season of their birth. Thus, winter weight loss could be partly attributable to the mortality of the first cohort in autumn, which would only have a slight effect upon population age structure. However, most of the mortality in the first cohort, particularly in males, occurs in midsummer (P e r r i n, in prep.) and therefore cannot be the cause of weight loss within the population. This is supported by the research of $\mathrm{M} \mathrm{arkov}, \mathrm{C} \mathrm{hris} \mathrm{to} \mathrm{V}$ \& Gliwicz (1972), Z e jda (1967) and Gliwicz (1975) on C. gla- 
reolus. Thus, it is suggested that low winter weight of C. gapperi is primarily due to weight loss by early cohorts, and to an inhibition of weight gain in late cohorts.

Spring growth of C. gapperi preceded snow melt and hence marked increases in primary production and food availability, but occurred simultaneously with gonad maturation ( $\mathrm{Per} r$ in, in prep.). This suggests

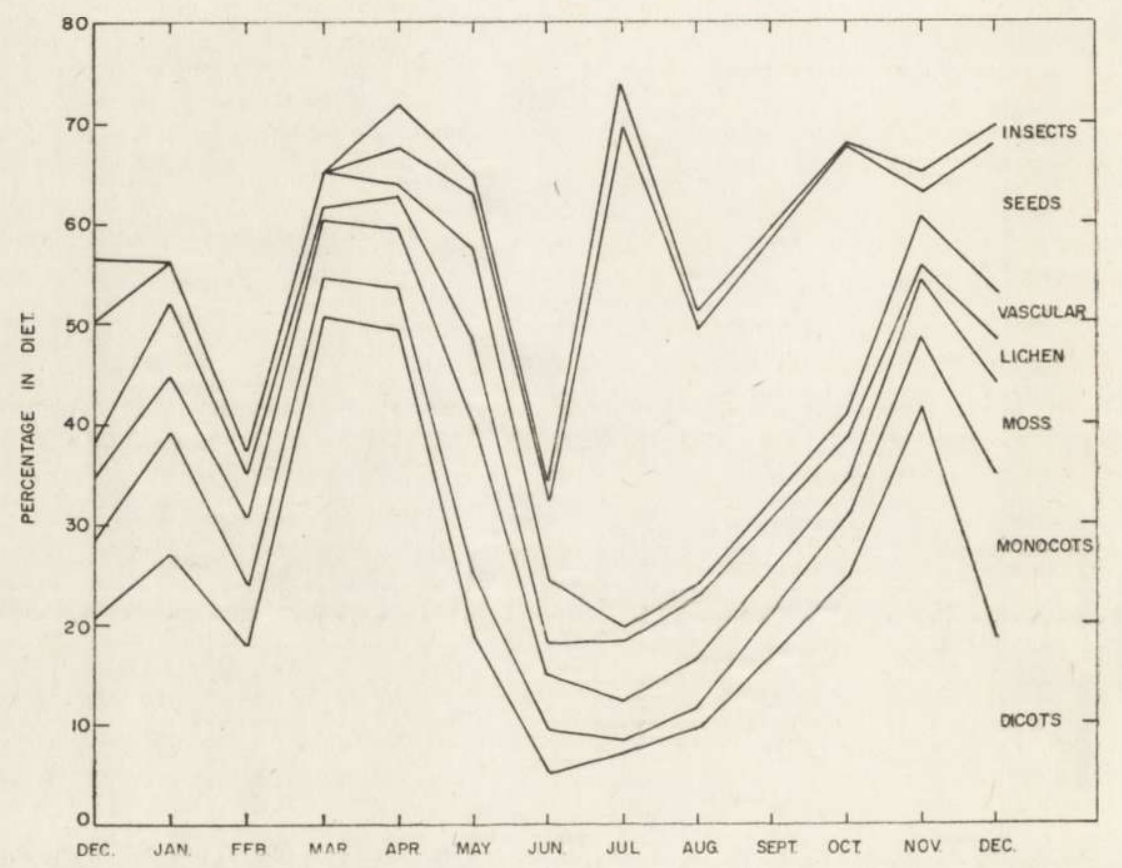

Fig. 7. Composition of the diet of wild C. gapperi throughout the sample period.

that change in daylength ( $\mathrm{R} \circ \mathrm{t} h, 1974)$ is the proximate factor regulating the onset of growth rather than food availability. Cessation of growth in C. gapperi occurred when the diet contained a high proportion of nutritious seeds and at least two months before snow fall, suggesting perhaps a daylength cue. Chitty, Pimental \& Krebs (1968) and Ryszkowski (1969) have similarly recorded the cessation of reproduction and growth when food supplies are abundant. Thus, it appears that the proximate cause of growth in C. gapperi is related to daylength and sexual maturation rather than to food supply, which might however, be the ultimate controlling factor. If weight gain to adult weight requires certain hormone levels, as proposed by $\mathrm{T} \mathrm{u} \mathrm{r} \mathrm{č} \mathrm{e} \mathrm{k}$ (1954), the action of hormones could be the mechanism producing weight 
change in response to a cue such as daylength. Such a system would explain why seasonal body weight fluctuations of $C$. gapperi are apparently out of phase with changes in food availability.

Winter inhibition of growth and reproduction in C. gapperi must lead to a conservation of energy. Indeed in C. rutilus, the daily caloric requirements are approximately $30 \%$ less in winter than summer owing to weight loss (Rosenmann, Morrison \& Feist, 1975). However, with low ambient temperature more energy is required for thermo-

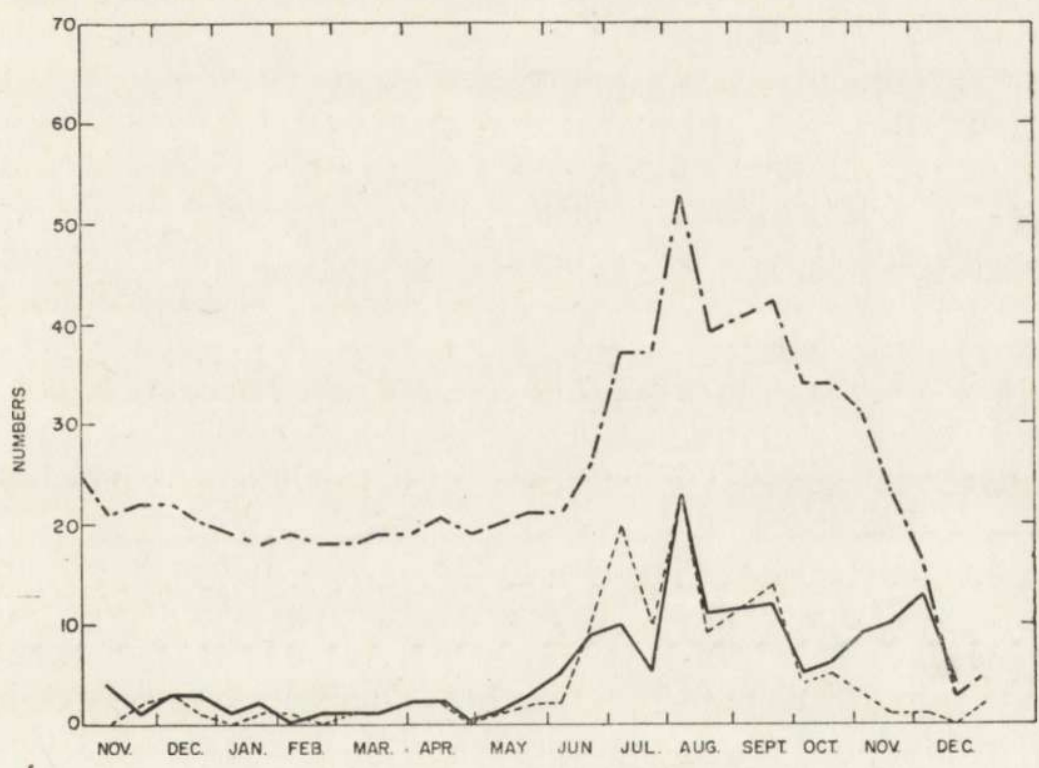

Fig. 8. Changes in numbers of C. gapperi on the live-trapped grid throughout the sample period.

Total numbers (.-.) are indicated separately from the first capture of individuals, i.e., natality and/or immigration (-- ), and from last captures of individuals, i.e., mortality and/or emigration (-

genesis but since energy requirements are related to body weight, energy for thermoregulation can be reduced in winter by a small body mass (M e z h zherin, 1964; M c N a b, 1971). Also, low weight is associated with a lower metabolic rate in C. glareolus (G ó r e c ki, 1968), and must aid energy conservation. Thus, it is suggested that winter weight loss in C. gapperi is an adaptive mechanism enhancing energy conservation and consequently survival.

Significant levels of dehydration occurred in C. gapperi in winter and have been reported in several other rodents (W h i t n e y, 1973; P u c e k, 1973; S a w icka-Kapusta, 1968). It is often associated with low winter weights and low metabolic rates in microtines ( $\mathrm{H}$ a n s S on \& 
Grodziński, 1970), and with pelage changes in Peromyscus ( $\mathrm{H}$ a ywa r d, 1965). Winter dehydration in C. gapperi might be part of an adaptive response to cold conditions, associated with reduced energy expenditure or improved insulation, but this needs investigation and verification.

There was no annual cycle of fat storage in C. gapperi and a similar result has been reported in the detailed study by Evans (1973) on Microtus agrestis. It is suggested that the pattern of winter fat accumulation in rodents (Fedyk, 1974; Sawicka-Kapusta, 1968; Se a l a nder, 1972; H sia-Wu-ping \& Sun-Chung-lu, 1963) is a great oversimplification of complex temporal changes in lipid metabolism. P u cek (1973) has shown that maximum fat levels of rodents may occur at any time of the year; $\mathrm{Hsia}-\mathrm{Wu}-\mathrm{ping} \& \mathrm{Sun}-$ Chung-lu (1963) have suggested possible differences in fat content with the cyclical phase of populations. It is often assumed that high fat levels act as energy reserves but Evans (1973) has demonstrated that fat reserves of $M$. agrestis, equivalent to those of $C$. gapperi, are only sufficient to maintain a non-feeding vole for nine hours. It is therefore concluded that fat deposition in C. gapperi does not act as a seasonal energy store, but might be concerned with insulation or possibly circadian changes in energy utilisation.

There was no significant increase in fat content of female Clethrionomys gapperi during the breeding season although Microtus deposit fat at this time (Evans, 1973; I ver s on \& T u rner, 1975). The absence of fat accumulation in breeding female $C$. gapperi might be due to extremely high energy demands associated with pregnancy and lactation ( $\mathrm{Kaczmarski}$, 1966), but this is unlikely since similar metabolic changes occur in Microtus ( $\mathrm{Migula}$, 1969; Trojan \& Wojciechowska, 1967). Thus, the observed difference might be associated with different foraging strategies or feeding habits. However, increases in protein in C. gapperi in the breeding season were small but consistent with those recorded for Microtus (Evans, 1973; Iverson \& Turn e r, 1975).

Since protein contents of pregnant C. gapperi were similar to those of non-pregnant individuals, body protein was not utilised for embryo production, and thus protein ingestion and assimilation must have increased to meet the increased demands. Although protein levels were generally stable, losses occurred during the population decline. This may have been indicative of protein shortage and nutritional stress, since lipid content was also depressed, and mineral content elevated.

The spring increase in mineral carcass content was temporally associated with spring growth, and the loss of minerals in autumn with loss 
of weight. Only at these times did females contain significantly more minerals than males. These differences might therefore be related to differences in metabolism or endocrinological changes associated with the onset and cessation of growth and reproduction.

In C. gapperi there was a seasonal change in the diversity of food items eaten, and their relative abundance, as occurs in other Clethrionomys species (K a le la, 1957; Z e manek, 1972; Mille r, 1954; Wa tts, 1968; Holišova, 1966). Hansson (1972) has proposed a hypothesis that suggests that feeding habits of herbivorous small rodents change from the protein-rich food required for growth and reproduction in summer, to a winter diet low in protein but high in carbohydrate which supplies energy for respiration and maintenance. This dietary switching is undoubtedly due to the relative abundance of preferred foods, such as insects (O b r te 1, 1973). In C. gapperi, proteinaceous seeds and insects formed an important part of the summer diet, that was almost absent in winter. Most of the plant food taken in winter consisted of dead dicotyledons, which are low in protein content (B l is s, 1971) but probably contain sufficient carbohydrate (M c B e e, 1971) for maintenance. Such seasonal changes in diet quality must influence maternal nutrition, and affect weaning success and the growth and survival of juveniles, but little information is available.

It is interesting to compare the differences in C. gapperi body composition for the declining population of the $1974 / 5$ winter with those from the previous winter. Although the weather and population density were different in the two years ( $\mathrm{Per}$ rin, in prep.) the composition of the diet for the two periods was almost identical. Hence any observed differences in body composition were not likely to have been caused by a change in food availability, but may have been associated with changes in food quality. Lack of snow cover caused freezing of the normally subnivean forest floor vegetation which might have affected food quality or the voles foraging behaviour, and caused greater exposure to predators. Body weight and water content of the carcasses was similar for both winters, but fat content was reduced in the declining population. In fact, the fat content of $9.1 \pm 0.9 \%$ was one of the lowest values recorded, and was only slightly above the level of fat retained at death $(7.9 \pm$ $1.4 \%$ ) in starved $M$. agrestis ( $\mathrm{E} v$ a n s, 1973), indicating that fat reserves had been depleted. Protein content was reduced in voles from the declining population but was not significantly lower than those from the peak population. This reduced protein content, which was associated with a high mineral content, might be indicative of protein breakdown and its utilisation by the body. Whether such changes in body composition 
in relation to density changes are meaningful is unknown but the temporal synchrony is suggestive of a positive correlation.

For C. gapperi it has been shown that seasonal changes occur in diet, body weight and carcass hydration. Body weight and water content appear to change in an adaptive manner in relation to a strongly seasonal environment. However, fat does not constitute a seasonal energy reserve, and must have another function, perhaps concerned with insulation or short term changes in energy requirements. Protein and mineral contents are essentially constant but exhibit small fluctuations possibly due to rapid growth or to nutritional stress.

Although causal relationships between nutrition and seasonal changes in growth rate have been demonstrated in Microtus arvalis ( $\mathrm{M}$ a $\mathrm{r} \mathrm{t}$ i n e t \& Spitz, 1971), there is little positive information to link nutrition directly with reproductive success ( $\mathrm{E} \vee \mathrm{n} \mathrm{s}$, 1973) or population density ( $\mathrm{H}$ of $\mathrm{f} \mathrm{m}$ a n, 1958; T a s $\& \mathrm{~K}$ a l e la, 1971). However, it is known that an increased food supply may lengthen the reproductive season ( $\mathrm{H}$ a n ss o n, 1971) or cause the onset of reproduction to be shifted forward (W a t ts, 1970; Andrzejewski, 1975) and may modify the onset of puberty ( $\mathrm{Z} \mathrm{e} \mathrm{j} \mathrm{d} \mathrm{a,} \mathrm{1962).} \mathrm{Nevertheless} \mathrm{more} \mathrm{information} \mathrm{is} \mathrm{required}$ for Clethrionomys populations. Future research must examine food selectivity in relation to nutrient content and reproductive success, for all phases of the population cycle.

Acknowledgements: I wish to express my gratitude, thanks and appreciation for the help that I have received from the members of staff of the Environmental Research Branch, Whiteshell Nuclear Research Establishment, Pinawa, Manitoba, and in particular to Dr. S. L. Iverson for making the study possible. The project was conducted whilst I was in receipt of a National Research Council of Canada Postdoctoral Research Fellowship, and was financed by Atomic Energy of Canada Limited.

\section{REFERENCES}

1. Allen E. S., Grimshaw H. M., Parkinson J. A. \& Quarmby C., 1974: Chemical Analysis of Ecological Materials. Blackwell Sci. Publ. Oxford.

2. Andrzejewski T., 1975: Supplementary food and the winter dynamics of bank vole populations. Acta theriol., 20: 23-40.

3. A very G. S. Jr., 1933: Structure and development of the tobacco leaf. Amer. J. Bot., 20: $565-592$.

4. B ergstedt B., 1965: Distribution, reproduction, growth and dynamics of the rodent species Clethrionomys glareolus (Schreber), Apodemus flavicollis (Melchior) and Apodemus sylvaticus (Linne) in southern Sweden. Oikos, 16: $132-160$.

5. B lis s L. C., 1971: Arctic and alpine plant life cycles. Ann. Rev. Ecol. Syst., 2: $405-438$.

6. Boikova F. I. \& Boikov V. N., 1972: The dynamics of changes in body weight and of the principal morphological features of the northern red-backed vole during autumn and winter in the subarctic. Ekologiya, 2: 44-51. 
7. Brown E. B., III, 1973: Changes in patterns of seasonal growth of Microtus pennsylvanicus. Ecology, 54: 1103-1110.

8. Bujalska G. \& Gliwicz J., 1968: Productivity investigation of an island population of Clethrionomys glareolus (Schreber, 1780). III. Individual growth curve. Acta theriol., 13: 427-433.

9. Chitty D., Pimentel D., \& Krebs C. J., 1968: Food supply of over-wintered voles. J. Anim. Ecol., 37: 113-120.

10. E s a u K., 1967: Plant Anatomy. John Wiley and Sons, Inc. New York.

11. Evans D. M., 1973: Seasonal variations in the body composition and nutrition of the vole Microtus agrestis. J. Anim. Ecol., 42: 1-18.

12. Fedy k A., 1974: Gross body composition in postnatal development of the bank vole. II. Differentiation of seasonal generations. Acta theriol., 19: 403-427.

13. Field A. C., 1975: Seasonal changes in reproduction, diet and body composition of two equatorial rodents. E. Afr. Wildl. J., 13: 331-235.

14. Fuller W. A., Stebbins L. L., \& Dyke G. R., 1969: Overwintering of small mammals near Great Slave Lake northern Canada. Arctic, 22: 34-55.

15. Gliwicz J., 1975: Age structure and dynamics of numbers in an island population of bank voles. Acta theriol., 20: 57-69.

16. Górecki A., 1968: Metabolic rate and energy budget in the bank vole. Acta theriol., 13: 341-365.

17. Hans s on L., 1971: Estimates of the productivity of small mammals in a south Swedish spruce plantation. Ann. Zool. Fenn., 8: 118-126.

18. Hanss on L., 1972: Seasonal changes in physiology and nutrition of herbivorous small rodents. Aquilo, Zool., 13: 53-55.

19. Hansson L. \& Grodziński W., 1970: Bioenergetic parameters of the field vole Microtus agrestis L. Oikos, 12: 76-82.

20. H a y ward J. J., 1965: The gross body composition of six geographic races of Peromyscus. Can. J. Zool., 43: 297-308.

21. H of $\mathrm{fman}$ R. S., 1958: The role of reproduction and mortality in population fluctuations of voles (Microtus). Ecol. Monogr., 28: 79-109.

22. Holišova V., 1966: Food of an overcrowded population of the bank vole, Clethrionomys glareolus Schreb., in a lowland forest. Zool. Listy., 15: 207-244.

23. Hsia-Wu-ping \& Shun-Chung-lu, 1963: On the relative fatness of the red-backed vole, Clethrionomys rutilus Pall. Acta Zool. Sinica., 15: 33-43.

24. Hyvarinen H. \& H eikura K., 1971: Effects of age and seasonal rhythm on the growth patterns of some small mammals in Finland and in Kirkeness, Norway. J. Zool. Lond., 165: 545-556.

25. Iverson S. L. \& Turner B. N., 1974: Winter weight dynamics in Microtus pennsylvanicus. Ecology 55: 1030-1041.

27. I vers on S. L. \& T urne r B. N., 1975: Seasonal variation in body composition in the meadow vole (Microtus pennsylvanicus). [In: "Prairie: A Multiple View" M. K. Wali, ed.]. Univ. North Dakota Press, Grand Forks.

28. $\mathrm{Kaczmarski}$ F., 1966: Bioenergetics of pregnancy and lactation in the bank vole. Acta theriol., 11: 409-417.

29. Ka le la O., 1957: Regulation of reproduction rate in subarctic populations of the vole Clethrionomys rufocanus (Sund.). Suomal. Tiedekat. Toim., 34: 1-60.

30. Kre bs C. J. \& M yers J. H., 1974: Population cycles in small mammals. Adv. Ecol. Res., 8: 267-399.

31. Lin s ba u er K., 1930: Die Epidermis. [In: „Handbuch der Pflanzenanatomie«]. 4, 27. Linsbauer. 
32. Markov G., Christov L., \& Gliwicz J., 1972: A population of Clethrionomys glareolus pirinus on the Vitosha Mountain, Bulgaria. I. Variations in numbers and age structure. Acta theriol. 17: 327-335.

33. Martinet L. \& Spitz F., 1971: Variation saisonnières de la croissance et de la mortalité du Campagnol des champs Microtus arvalis. Role du photoperiodisme et de la vegetation sur ces variations. Mammalia, 35: 38-84.

34. McBee R. H., 1971: Significance of intestinal microflora in herbivory. Ann. Rev. Ecol. Syst. 2: 165-176.

35. M c N a b B. K., 1971: On the ecological significance of Bergmann's rule. Ecology, 52: $845-854$.

36. Metcalfe C. R. \& Chalk L., 1972: Anatomy of the Dicotyledons. 1 and 2, Oxford. Clarendon Press.

37. Mezhzherin V. A., 1964: Dehnel's phenomenon and its possible explanation. Acta theriol. 8: 95-114.

38. Migula P., 1969: Bioenergetics of pregnancy and lactation in European common vole. Acta theriol., 14: 167-179.

39. Miller R. S., 1954: Food habits of the wood mouse Apodemus sylvaticus (Linne 1758) and the bank vole Clethrionomys glareolus (Schreber 1780), in Wytham Woods, Berkshire. Saugetierk. Mitt., 2: 108-114.

40. Nea 1 B. R., Pulkinen D. A., \& O wen B. D., 1973: Comparison of faecal and stomach content analysis in the meadow vole (Microtus pennsylvanicus). Can J. Zool. 51: 715-721.

41. O brtel R., 1973. Animal food of Clethrionomys glareolus in a lowland forest. Zool Listy. 22: 111-116.

42. Perrin M. R., (in press): The role of reproduction, survival and territoriality in the seasonal dynamics of Clethrionomys gapperi populations. Acta theriol.

43. Perrin M. R., 1978: Molar root-length as an indicator of age in Clethrionomys gapperi. Acta theriol., 23: 423-434.

44. Pucek M., 1973: Variability of fat and water content in two rodent species. Acta theriol. 18: $57-80$.

45. Pulkinen D. A., 1971: Food habits of the meadow vole (Microtus pennsylvanicus) and their relationships to nutritional differences in available foods. M. Sc. Thesis, Univ. of Saskatchewan, Saskatoon.

46. Ros enmann M., Morris on P., \& F e is t D., 1975: Seasonal changes in the metabolic capacity of red-backed voles. Physiol. Zool. 48: 303-310.

47. R oth R. R., 1974: The effect of temperature and light combinations upon the gonads of male red-backed voles. Biol. Reprod., 10: 309-314.

48. Ryszkowski L., 1969: Estimates of consumption of rodent populations in different pine forest ecosystems. [In: »Energy Flow Through Small Mammal Populations Eds. Petrusewicz, K. and Ryszkowski, L.]. 281-289. Polish Sci. Publ. Warszawa.

49. Sawicka-Kapusta K., 1968: Annual fat cycle of field mice, Apodemus flavicollis (Melchior, 1834). Acta theriol., 13: 329-339.

50. S e a la nd e r J. A. Jr., 1972: Circum-annual changes in age, pelage characteristics and adipose tissue in the northern red-backed vole in interior Alaska. Acta theriol., 17: 1-24.

51. Shenk J. S., Elliot F. C., \& Thomas J. W., 1970: Meadow vole nutrition studies with semisynthetic diets. J. Nutr., 100: 1437-1446.

52. Tast J. \& Kalela O., 1971: Comparison between rodent cycles and plant production in Finnish Lapland. Ann. Acad. Sci. Fenn. 186: 1-14. 
53. Trojan P. \& Wojciechowska B., 1967: Resting metabolism during pregnancy and lactation in the European common vole Microtus arvalis (Pall.). Ekol. pol. A., 15: 811-917.

54. Turcek F. J., 1954: Changes in the body weight of A. flavicollis and C. glareolus on Polona 1952. Biologia, 9: 569-575.

55. W a t $\mathrm{s}$ o n R. W., 1942: The effect of cuticular hardening on the form of epidermal cells. New Phytol., 41: 223-229.

56. W a t t s C. H. S., 1968: The foods eaten by wood mice (Apodemus sylvaticus). and bank voles (Clethrionomys glareolus) in Wytham Woods, Berkshire. J. Anim. Ecol., 37: 25-41.

57. W a t t s C. H. S., 1970: A field experiment on intraspecific interactions in the redbacked vole, Clethrionomys gapperi. J. Mammal. 51: 341-347.

58. Whitney P. H., 1973: Population biology and energetics of three species of small mammals in the taiga of interior Alaska. Ph. D. Thesis, Univ. Alaska. $254 \mathrm{pp}$.

59. William s P. C., 1973: Use of titanium dioxide as a catalyst for large scale Kjeldahl determination of total nitrogen content of cereal grains. J. Sci. Fd. Agric., 24: 343.

60. Z ejda J., 1962: Winter breeding in the bank vole, Clethrionomys glareolus Schreb. Zool. Listy., 11: 309-321.

61. Z ejda J., 1967: Mortality of a population of Clethrionomys glareolus Schreb. in a bottomland forest in 1964. Zool. Listy., 16: 221-238.

62. $\mathrm{Z} \mathrm{ejda} \mathrm{J.,} \mathrm{1971:} \mathrm{Differential} \mathrm{growth} \mathrm{of} \mathrm{three} \mathrm{cohorts} \mathrm{of} \mathrm{the} \mathrm{bank} \mathrm{vole,} \mathrm{Cle-}$ thrionomys glareolus Schreb. 1780. Zool. Listy., 20: 229-245.

63. Z e m a n e k M., 1972: Food and feeding habits of rodents in a deciduous forest. Acta theriol., 17: 315-325.

Accepted, March 6, 1979.

M. R. PERRIN

\author{
SEZONOWA ZMIENNOSC TEMPA WZROSTU, SKŁADU CIAŁA I DIETY \\ U CLETHRIONOMYS GAPPERI
}

\title{
Streszczenie
}

Zbadano tempo wzrostu i skład ciała Clethrionomys gapperi V i g o r s, $1830 \mathrm{w}$ zależności od sezonu i rodzaju pokarmu (Tabela 1). Zwierzęta pochodziły z populacji zamieszkującej lasy sosnowe (Picea mariana) w południowo-wschodniej Manitobie. Zimowe obniżanie się ciężaru ciała jest związane $\mathrm{z}$ odwodnieniem organizmu (Ryc. 3) i nie może być przypisane strukturze wiekowej populacji lub jakimkolwiek zmianom w diecie.

Wiosenny wzrost zwierząt i podniesienie się zawartości białka w organizmie, występuje wcześniej u samców niż u samic i nie jest odpowiedzią na zmianę rodzaju pokarmu. Zjawisko to związane jest $\mathrm{z}$ dojrzewaniem płciowym i wydłużaniem się dnia. Poziom białka i popiołu (Tabela 1,2 ; Ryc. 5,6 ) zazwyczaj stały nawet w okresie ciąży, zmienił się gdy liczebność nornic obniżyła się w ciągu zimy 1974 r. Dieta C. gapperi ulegała zróżnicowaniom sezonowym (Ryc. 7). Latem zwierzęta pobierały pokarm bogatszy $\mathrm{w}$ białko, w porównaniu z zimą, gdyż był on $\mathrm{w}$ tym czasie bar- 
dziej dostępny. Określa to odżywianie się matek oraz wzrost i przeżywanie młodych zwierząt. Początek i czas trwania rozrodu nie zależy od zmian w diecie.

Obniżanie się liczebności populacji (Tabela 3 ; Ryc. 8) związane było z występowaniem słabej okrywy śnieżnej i wyczerpywaniem zapasów tłuszczu (ryc. 4) i białka w organizmie chociaż dieta nornic była taka sama jak w poprzednim roku badań. Smiertelność mogła być wynikiem obniżania się jakości pokarmu podczas gdy wymagania energetyczne na zabezpieczenie termoregulacji i kosztów utrzymania były wysokie. Pewien wpływ mogła mieć też niedostateczna okrywa śniegowa wpływająca na zmianę behawioru pokarmowego nornic i powodująca większe narażenie ich na działalność drapieżników 